\section{UNIVERSITY \\ of DEBRECEN}

FACULTY OF

HEALTH

NYÍREGYHÁZA

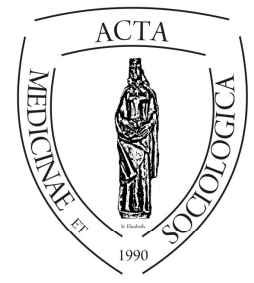

ACTA

MedSoc

VOLUME 3.

2013

\title{
The influence of different pathogenically based treatment schemes on the endothelium dysfunction indexes in patients with liver cirrhosis
}

\author{
Rusin V.I., Sirchak E.S., Ivachevskij M.M., \\ Petrichko O.I.,
}

Uzhhorod National University, Medical Department (Ukraine, Uzhhorod)

\begin{abstract}
The influence of different pathogenically based treatment schemes on the endothelium dysfunction indexes in patients with liver cirrhosis.

The data about the complex examination and treatment of 64 patients is given. The efficiency of prescribing angiotensin II receptor blocker was proved compared with angiotensin-converting enzyme inhibitors and $\beta$-blockers in combination with prebiotics, probiotics and L-arginine medical preparations. It is found that there are more manifested positive changes in the indexes of dysfunction of endothelium in patients from group 3 (usage of valsartan, $\mathrm{n}=24$ ), namely: decrease of $\mathrm{D}$-dimer level to $1,68 \pm 0,11$ $\mathrm{ng} / \mathrm{ml}$ from $4,01 \pm 0,12 \mathrm{ng} / \mathrm{ml}$; endothelin-1 level to $0,52 \pm 0,04 \mathrm{fmol} / \mathrm{ml}$ from $1,12 \pm 0,22$ $\mathrm{fmol} / \mathrm{ml}$; the level of PgF2 $\alpha$ to $97,1 \pm 2,2 \mathrm{pg} / \mathrm{ml}$ from $217,5 \mathrm{pg} / \mathrm{ml}$; the level of Pg I2 to $79,2 \pm 4,5 \mathrm{pg} / \mathrm{ml}$ from $218,4 \pm 6,8 \mathrm{pg} / \mathrm{ml}(\mathrm{p}<0,01)$. This indicates the effect of the proposed treatment scheme on the dysfunction of endothelium indexes dynamics that lies within the basis of the treatment of complication progression at liver cirrhosis.

Key words: liver cirrhosis, endothelial dysfunction, angiotensin II receptor blockers, L-arginine, probiotics.
\end{abstract}

DOI: $10.19055 / \mathrm{ams} .2013 .4 / 11 / 2$ 
Összefoglalás. Különböző patogenetikailag megalapozott kezelési módszer hatása az endothel diszfunkció súlyossági mutatóira májcirrózisos betegeknél

A kutatás során 64 májcirrózisos beteg vizsgálati eredményeinek és kezelésének összegzésére került sor. Eredményeink az angiotenzin II-receptor blokkolók hatékonyságát bizonyították a $\beta$-receptor blokkolókkal és angiotenzin-konvertáz enzim bénítókkal szemben probiotikum és L-arginin készítményekkel kombinálva májcirrózis esetén. A 3. kutatási csoport betegeinél (valszartán alkalmázása, $n=24$ ) bizonyítottan lényegesebb pozitív értékeket tapasztaltunk az endothel diszfunkció mutatóinak dinamikájában, azaz, a D-dimer szint 1,68 $\pm 0,11 \mathrm{ng} / \mathrm{ml}$-re csökkent 4,01 $\pm 0,12 \mathrm{ng} / \mathrm{ml}$-röl, az endotelin-1 szint 0,52 $\pm 0,04 \mathrm{fmol} / \mathrm{ml}$-re csökkent 1,12 $\pm 0,22 \mathrm{fmol} / \mathrm{ml}$-ról, aPgF2a szint 97,1 $\pm 2,2 \mathrm{pg} / \mathrm{ml}$-re

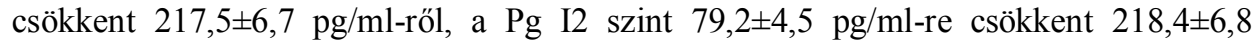
pg/ml-röl $(\mathrm{p}<0,01)$. A kutatás során kapott adatok alátámasszák a javasolt kezelési séma (angiotenzin II-receptor blokkolók, probiotikumok, L-arginin készítmények) eredményességét az endothel diszfunkció súlyosságának csökkentésére, ami alapul szolgálhat a szövődmények progressziójának megelőzéseben májcirrózisos betegeknél.

Kulcsszavak: májcirrózis, endothel diszfunkció, angiotenzin II-receptor blokkolók, L-arginin, probiotikumok.

Symptomatic treatment of patients with liver cirrhosis aims at decreasing the risk of developing complications of portal hypertension, such as hemorrhage, hepatic encephalopathy, hepatorenal syndrome, and improving the life quality of the given patients $[2,12,13]$. An important stage in the treatment of portal hypertension was the application of non-selective $\beta$-adreno-blocking agents and angiotensinconverting enzyme inhibitors for the treatment of hemorrhages of varicose veins of the esophagus and stomach [7]. $\beta$-blockers cause the desired hemodymanic effect only among $30-40 \%$ of the patients, while in a part of patients they cause the declination of liver functions due to the decrease of general blood circulation capacity of the organ. Inhibitors of angiotensin-converting enzyme decrease gradient of phleboid liver pressure, but due to a significant decrease of the systemic arterial pressure they cause further declination of the hyperdynamic blood circulation. Due to this, the search for new methods to decrease the pressure of the portal system with the help of medical preparations is continued [4,5].

It is known that L-arginin has been successfully used for many years for treating liver diseases [14]. It is proven that L-arginin based medical preparations decrease the concentration of ammonia due to the enhancement of urea synthesis (by $80 \%$ ) and the enhancement of glutamine synthesis, decreasing the manifestation of hepatic encephalopathy $[8,9,10]$. Researches over the recent years have also proven the laudable effect of L-arginin on the function of vascular endothelium which is worth considering during the complex treatment of patients with chronic diffusive liver disease, since the preventive treatment of complex forms of liver cirrhosis largely depends on the correction of endothelium dysfunction. 


\section{Aim of the research}

A comparative assessment of the efficiency of different pathogenically based schemes of portal system pressure correction and their influence on the endothelial dysfunction indicators in patients with liver cirrhosis.

\section{Materials and methods of the research}

We took 64 patients under observation with liver cirrhosis that had hemorrhage of varicose veins of esophagus and stomach (in anamnesis), which were treated in the gastroenterology, surgical and intensive care departments of the Transcarpathian Regional Clinical Hospital of A. Novak. Among the examined patients the number of men prevailed $40(62,5 \%)$, aged $51,7 \pm 6,2$ years, and that of women $24(37,5 \%)$, aged 47,7 $\pm 5,9$ years. The control group consisted of 30 practically healthy persons aged 26 to 62 years, whose average age was $41,3 \pm 2,1$ years. Among them there were 16 men (53,3\%), and 14women (46,7\%).

The diagnosis of liver cirrhosis was made according to their complaints, medical history, laboratory (blood chemistry, identification of markers of hepatitis viruses $\mathrm{B}, \mathrm{C}$ ) and instrumental (ultrasound of the abdomen, esophagogastroduodenoscopy, radioisotope, and angiography) methods of research. The degrees of liver affection were determined by C13-methacetin breath test and specially designed tests on the basis of laboratory blood indicators were also applied (Forns, Fibroindex, Fib-4, APRI, HALT-C, MDA, GUCI, FPI, PGA and PGAA).

In order to identify changes of the cardiovascular system, all patients with liver cirrhosis had electrocardiography (ECG) done, as well as Holter monitoring and echocardiography. Ultrasonic examinations of the heart were done on the automatic diagnostic device, "ACUSON" $128 \mathrm{XP}$, in M- and B-modes in accordance with a generally accepted methodology. By doing it the beat index (Bi) was also measured, as well as the left ventricular ejection fraction (LV EF) and the heart index (Hi).

Daily monitoring of arterial pressure (AP) was done using "AVRM-04" set ("Meditech", Hungary). Arterial pressure measurements were done every 15 minutes between 6:00 - 22:00 and every 20 minutes between 22:00-6:00. The following indexes were analyzed: systolic AP (SAP), diastolic AP (DAP), average day AP (SAPd, DAPd), average night AP (SAPn, SAPn), variability index (Vi) at day and night time SAP (Vi SAPd, Vi SAPn) and DAP (Vi DAPd, Vi DAPn), daily index (Di SAP, Di DAP). 
The index of vasoactive substances in blood serum of patients with liver cirrhosis was measured using the immunoenzymometric examination, namely: endothelin-1 (ET-1) using test-systems of "Biomedica" company (Austria); 6ketoprostaglandin F1 $\alpha$ (prostaciklin of blood serum PgI2) and prostaglandin F2 $\alpha$ (PgF2 $\alpha$ ), using Enzo Life Sciences test systems of "BCM Diagnostics" company (USA). The following indexes were also examined: the level of antithrombin (AT) III, D-dimer, von Willenbard factor (vWf), apolipoprotein A1, the level of insulin using chromogenic examination on Sysmex 500 and 560 set (Japan) using Siemens company reagents.

Ultrasonic duplex scanning of brachial artery was done using HDI-1500 set (USA) with the use of pulse waved Doppler detector 2,5 MG Hz and 5-10 MG $\mathrm{Hz}$ - "Zonarae" (USA). Endothelium-dependant vasodilatation (EDVD) of brachial artery was examined with the method, offered by D. Celermajer. The examination was done using two-dimensional scanning with synchronic ECG trace, the diameter of the artery was measured in B-mode, the change of the blood flow speed before and after the probe with reactive hyperemia was done in Doppler-mode. The simulation pulse of EDVD was the reactive hyperemia that is caused by the ferrule placed on the surface of the distally done examination. The diameter of the brachial artery was measured in a dormant state (after 10-15 minutes of rest). $200-300 \mathrm{mmHg}$ pressure was created in the ferrule for 5 minutes, after that the pressure was removed, the diameter and the speed of the blood flow were measured during 5 minutes right after removing the ferrule with 30 second intervals. The increase of the brachial artery diameter by $10 \%$ after 60-90 seconds, with reactive hyperemia in the background, was considered a normal reaction.

After the restoration of the artery diameter in 15 minutes, the patient took 0,5 $\mathrm{mg}$ of nitroglycerine sublingually. In this method, nitroglycerine is used as an endothelium-independent (EIVD) stimulation pulse, which causes relaxation of the periphery vessels. Measurements were repeated after 2 and 5 minutes after taking nitroglycerine. The reaction related to the increase of the blood flow was evaluated as the difference of the diameter in the 2nd minute after taking nitroglycerine and that of the primary diameter. An increase of $10 \%$ and over of the brachial artery on the background of reactive hyperemia is considered to be normal. A lower level of vasodilatation or vasoconstriction is considered to be a pathological reaction. Dysfunction of endothelium was verified at a significantly lower rate during the distention of vessels, than while taking nitrates [11].

All patients with liver cirrhosis on their diet background received basic treatment with hepatoprotectors, diuretics, desintoxication and vitamin therapy, lactulose and enterosorbents. If intestinal dysbiosis was indicated patients were prescribed antibacterial medication: ciprofloxacin $500 \mathrm{mg} 2$ times daily for 5 days. 
With the purpose of aiding the dysfunction of endothelium patients with liver cirrhosis received L-arginin based medical preparation: Gepadif (by 1 vial) dissolved in $200 \mathrm{mg}$ of $5 \%$ glucose solution intravenously during 7 days, with a further change to oral consumption of medical preparation by 2 capsules 3 times a day during 3 weeks or Tivortin ${ }^{\circledR}(4,2 \%$ L-arginin solution) in the following dosage: for the first 4 days $100 \mathrm{mg}$ twice a day intravenously, then during 10 days $100 \mathrm{mg}$ a day. Simultaneously patients took $20 \mathrm{mg}$ of Tivortin orally. Additionally, multiprobiotic Lacium ${ }^{\mathrm{TM}}$ was included into the treatment complex, which comprises Bifidobacterium bifidum, Bifidobacterium lactis (2 strains), Enterococcus faecium, Lactobacillus acidophilus (2 strains), Lactobacillus paracasei, Lactobacillus plantarum, Lactobacillus rhamnosus, Lactobacillus salivarius 1 capsule twice a day for two weeks.

Patients with liver cirrhosis who had hemorrhage of the varicose veins of esophagus and stomach (in anamnesis) were divided into groups depending on the mode of pressure control in the portal system:

Group $1 \quad(n=14)$ of patients with liver cirrhosis were given medical preparation from angiotensin-converting enzyme inhibitors group - captopril $25 \mathrm{mg}$ twice a day.

Group $2(n=26)$ of patients with liver cirrhosis were prescribed non-selective $\beta$-adreno-blocking agent propranol dozed individually under the control of heartbeat rate.

Group $3(n=24)$ of patients with liver cirrhosis were given medical preparation from angiotensin II receptor blockers group - valsartan - in individual dosage (by 40 or $80 \mathrm{mg}$ daily).

Analysing and processing the results of patients' examination were carried out using Statistica 6.0, a statistical software package of Microsoft Exel 7.0.

\section{Results and discussion}

After clinical and laboratory examinations of all the patients with liver cirrhosis we divided them into classes of severity based on Child-Pugh, taking into account the level of bilirubin, almubin, prothrombin indexes and the presence or absence of ascites and hepatic encephalopathy. Class A according to Child-Pugh included $14(21.9 \%)$ patients, class B 26 (40.6\%) patients and class C 24 $(37.5 \%)$ patients.

Besides the assessment of the clinical symptomatology dynamics and the control research of general laboratory and instrumental indexes, after the conducted complex treatment, patients with liver cirrhosis had an occasional weighting of the functional hepatocytes using C13-methacetin breath test, general 
cardiogemodynamic examination parameters and index of dysfunction of endothelium identification.

After the conducted complex differential treatment, a positive dynamics of the clinical and laboratory symptomatology was observed in patients with liver cirrhosis. After a repeated identification of a mass of functioning hepatocytes in patients with liver cirrhosis no significant changes in the indexes before and after the conducted treatment were observed. In patients with liver cirrhosis, after a repeated identification of a mass of functioning hepatocytes it increased only by $2.5 \pm 0.7 \%$ (from $28.4 \pm 5.2 \%$ to $30.9 \pm 2.7 \%$ - p $>0.05$ ).

While characterizing the changes in probe dynamics with reactive hyperemia among the examined patients with liver cirrhosis, it was stated that the utmost influence on the appearance of dysfunction of endothelium has a simultaneous usage of probiotics, L-arginine medical preparation combined with angiotensinII receptor blockers, that is, the complex treatment that was assigned for patients in group 3. However, it should be emphasized that in these patients the stages of dysfunction of endothelium manifestation suffered the most on the background of significant disorders in liver function, as all of them were representatives of $\mathrm{C}$ class according to Child-Pugh.

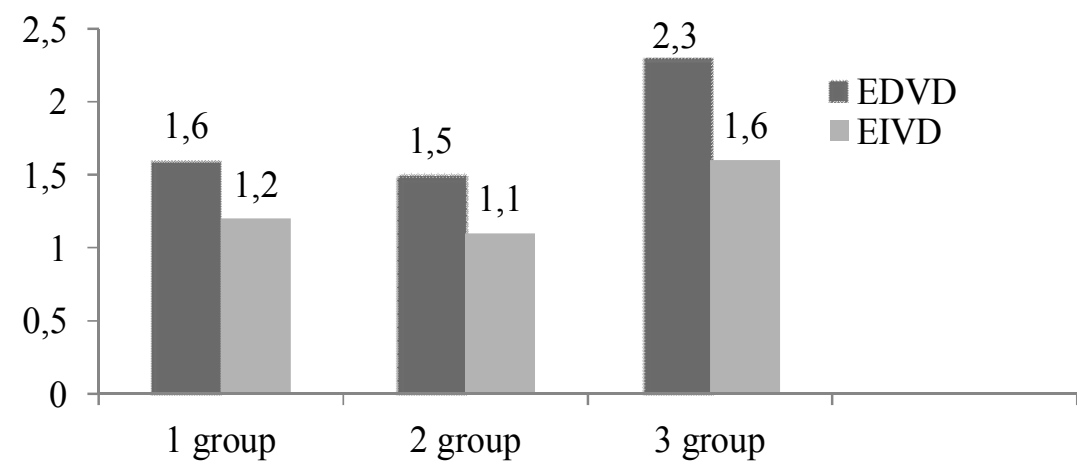

Chart 1. The rate of indexes of dysfunction of endothelium dynamics according to the results of the probe with reactive hyperemia in patients with liver cirrhosis under the influence of complex treatment.

The indexes of EDVD in patient group 3 increased by 2.3 timesfold compared with the indexes before the conducted treatment (before $10.3 \pm 1.2 \%$ from $5.7 \pm 1.8 \%$ - accordingly $\mathrm{p}<0.05$ ) (Chart1). In patients from group 1 and 2 a nearly similar EDVD and EIVD index dynamics were observed after the conducted complex treatment. Therefore, out of all the prescribed medical 
preparations for patients with liver cirrhosis, the complex treatment with the use of probiotics, L-arginine medical preparations and $\beta$-adreno-blocking agents had the biggest influence on the instrumental indexes of the dysfunction of endothelium. Angiotensin-converting enzyme inhibitors and non-selective $\beta$ adreno-blocking agents show an almost similar influence on the condition of vessel endothelium.

While characterizing the laboratory indexes of the dysfunction of endothelium in patients with liver cirrhosis after the conducted complex treatment, it has been found that the most significant positive dynamic is also observed in patients from group 3, a less significant influence is manifested by the complex treatment, that was assigned to patients from group 1, and the least significant influence was found after the course of treatment in patients from group 2 (Chart 2). In patients from group 1 the decrease in endothelin-1 and von Willenbard factor levels were observed with the same frequency, namely the level of endothelin-1 decreased from $0.57 \pm 0.04 \mathrm{fmol} / \mathrm{ml}$ to $0.38 \pm 0.05 \mathrm{fmol} / \mathrm{ml}$, the level of von Willenbard factor decreased from $189.0 \pm 44.0 \%$ to $126.0 \pm 23.0 \%$. The level of antithrombin III in this group of patients increased from $78.0 \pm 10.3 \%$ to $84.0 \pm 2.5 \%$. For patients from group 3 the most significant dynamic was observed while examining the level of D-dimer and endothelin- 1 . The level of D-dimer decreased to $1.68 \pm 0.11 \mathrm{ng} / \mathrm{ml}$ from $4.01 \pm 0.12 \mathrm{ng} / \mathrm{ml}$, and the level of endothelin- 1 - to $0.52 \pm 0.04 \mathrm{fmol} / \mathrm{ml}$ from $1.12 \pm 0.22 \mathrm{fmol} / \mathrm{ml}$. The least positive dynamic in patients from group 3 was manifested in the levels of antithrombin III (only by 1.4 times).

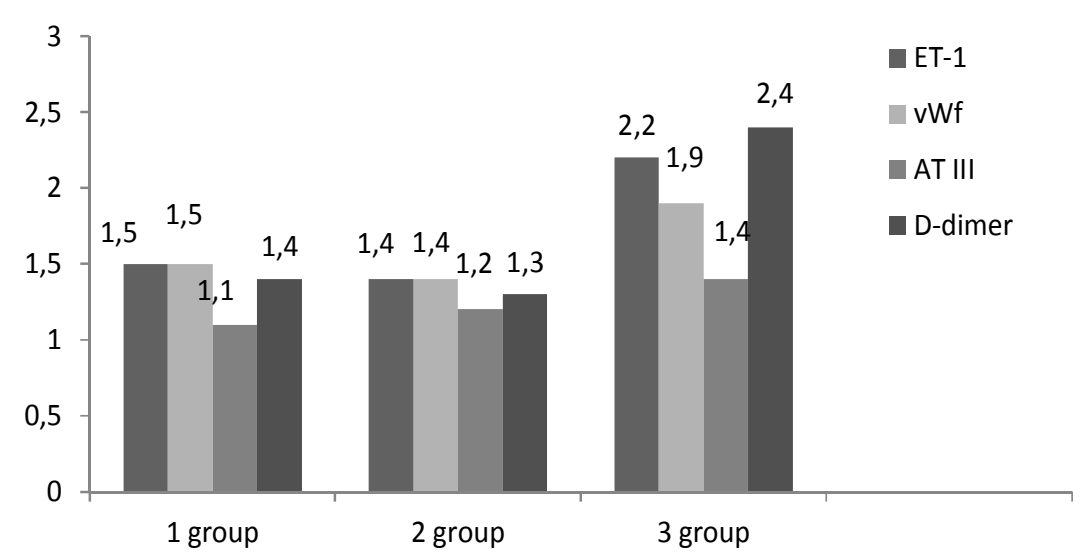

Chart 2. The rate of laboratory indexes of dysfunction of endothelium dynamics in patients with liver cirrhosis under the influence of complex treatment 
In patients with liver cirrhosis from group 1 and 2 the conducted complex treatment helped the manifestation of positive dynamics in almost the same rate as that of the indexes of prostaglandins (chart 3).

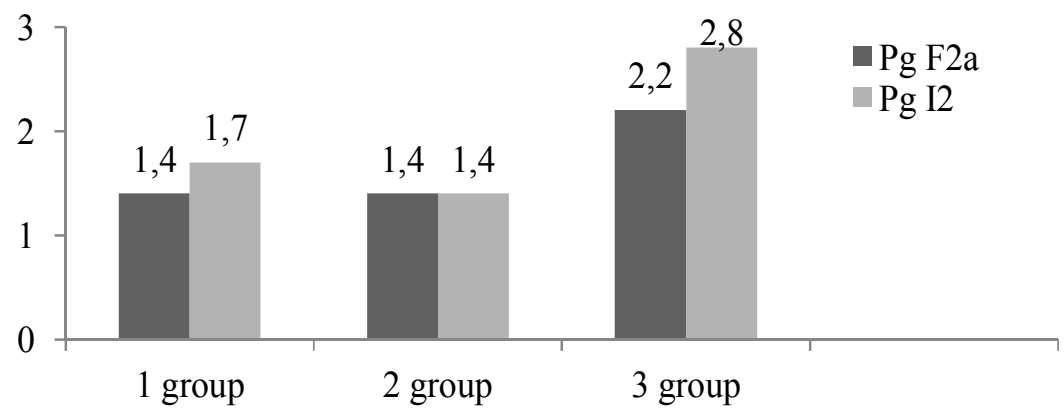

Chart 3. The rate of index dynamics of prostaglandin in blood serum in patients with liver cirrhosis under the influence of the complex treatment

The level of Pg I 2 as well as the level of Pg F2 $\alpha$ in patients from group 2 decreased after the treatment by 1.4 times, whereas in patients from group 1 by 1.7-1.4 times - accordingly $\mathrm{p}<0.05$. The most significant changes after the treatment were registered in patients from group 3, namely the level of prostaglandin F2 $\alpha$ decreased to $97.1 \pm 2.2 \mathrm{pg} / \mathrm{ml}$ from $217.5 \pm 6.7 \mathrm{pg} / \mathrm{ml}$, and the level of prostacyclin to $79.2 \pm 4.5 \mathrm{pg} / \mathrm{ml}$ from $218.4 \pm 6.8 \mathrm{pg} / \mathrm{ml}$. Between the given indexes, before and after the treatment in patients from group 3, a statically accurate difference is found $-\mathrm{p}<0.01$.

While studying the dynamics of arterial pressure indexes under the influence of complex treatment during daily monitoring, more significant unwanted changes, on the background of the complex treatment, were observed in patients with liver cirrhosis from group 1. The arterial pressure of patients with liver cirrhosis decreased the most on the background of taking angiotensin-converting enzyme inhibitors - that is an unwanted effect for this group of patients, due to the specifics of hyperdynamic circulation. In patients from group 1, SAPd decreased from $110.2 \pm 2.7 \mathrm{mmHg}$ to $95.3 \pm 4.6 \mathrm{mmHg}$. DAPd decreased on the background of taking captopril from $69.5 \pm 2.2 \mathrm{mmHg}$ to $59.3 \pm 1.8 \mathrm{mmHg}$. Patients from group 1 were registered with the highest daily surges between the indexes of arterial pressure: Di SAP after the treatment was $9.7 \pm 1.8 \%$, while Di DAP was $8.4 \pm 1.2 \%$. 
While treating patients with liver cirrhosis with non-selective $\beta$-adreno-blocking agents in dosage that normalizes the heartbeat rate and valsartan in individual dosage, no significant decrease of vessel blood pressure was observed. On the background of taking propranolol and valsartan (groups 2 and 3) no significant surges were observed in the system arterial pressure. In patients from group 2, while normalizing the heartbeat rate (to $75.3 \pm 7.7$ beats per minute), SAPd and DAPd decreased only by $2.3 \pm 1.4 \mathrm{mmHg}$. The Vi SAPd after the treatment was $12.1 \pm 1.7 \mathrm{mmHg}$, while the Vi DAPd was $8.6 \pm 1.2 \mathrm{mmHg}$.

In patients from group 3, the heartbeat rate decreased to $77.8 \pm 2.4$ beats per minute. SAPd after the treatment was $99.5 \pm 4.4 \mathrm{mmHg}$, before the treatment it was $101.7 \pm 6.3 \mathrm{mmHg}$. DAPd after the treatment was $60.2 \pm 3.3 \mathrm{mmHg}$, before the treatment it was $61.2 \pm 4.1 \mathrm{mmHg}$.

While doing an echocardiographic examination before the treatment, significant changes in the heart hemodynamics were observed - they were manifested by the parameters that are specific for a hemodynamic blood circulation, especially in patients with liver cirrhosis from group 3 (C class according to Child-Pugh). The beat index for patients from group 3 before the treatment decreased to $28.99 \pm 2.2 \mathrm{ml} / \mathrm{m} 2$, with lowered indexes of heart index to $2.59 \pm 0.81-\mathrm{min}-2-\mathrm{m}-2$, and also left ventricular ejection fraction to $58.1 \pm 3.6 \%$ (Table 1).

\begin{tabular}{|l|c|c|c|c|c|c|}
\hline \multirow{3}{*}{ Indigators } & \multicolumn{5}{|c|}{ Patients with liver cirrosis } \\
\cline { 2 - 7 } & \multicolumn{2}{|c|}{$\begin{array}{c}\text { 1 group (n=14) } \\
\text { treatment }\end{array}$} & \multicolumn{2}{|c|}{ 2 group (n=26) } & \multicolumn{2}{|c|}{ 3 group (n=24) } \\
\cline { 2 - 7 } & $\begin{array}{c}\text { before } \\
\text { treatment }\end{array}$ & $\begin{array}{c}\text { before } \\
\text { treatment }\end{array}$ & $\begin{array}{c}\text { after } \\
\text { treatment }\end{array}$ & $\begin{array}{c}\text { before } \\
\text { treatment }\end{array}$ & $\begin{array}{c}\text { after } \\
\text { treatment }\end{array}$ \\
\hline $\mathrm{Bi}, \mathrm{ml} / \mathrm{m}^{2}$ & $49,11 \pm 1,7$ & $45,87 \pm 2,2$ & $39,1 \pm 2,4$ & $44,2 \pm 3,5$ & $28,99 \pm 2,2$ & $36,1 \pm 3,5^{*}$ \\
\hline $\begin{array}{l}\mathrm{Hi}, 1-\mathrm{min}^{-2} \\
-\mathrm{m}^{-2}\end{array}$ & $4,22 \pm 0,5$ & $4,17 \pm 0,4$ & $3,41 \pm 0,5$ & $3,98 \pm 0,7$ & $2,59 \pm 0,8$ & $3,26 \pm 0,7^{*}$ \\
\hline $\mathrm{LV} \mathrm{EF}, \%$ & $61,4 \pm 3,3$ & $62,1 \pm 2,8$ & $60,7 \pm 2,1$ & $65,5 \pm 1,4^{*}$ & $58,1 \pm 3,6$ & $65,1 \pm 1,1^{*}$ \\
\hline
\end{tabular}

Table 1. The rate of cardio hemodynamic indexes according to echocardiographic data in patients with liver cirrhosis under the influence of complex treatment Note: * $-\mathrm{p}<0.05$ - a statically accurate difference was observed between the indexes in patients before and after the treatment.

While using $\beta$-adreno-blocking agents in complex treatment of patients from group 2 a decrease of diastolic dysfunction of myocardium in liver cirrhosis was observed, and also an increase of LV EF by $4.8 \pm 0.7 \%$, whereas as a result of it the beat index increased by $5.1 \pm 1.1 \mathrm{ml} / \mathrm{m} 2$. The most manifested positive 
changes were observed while using valsartan in patients with liver cirrhosis from group 3. In this group of patients LV EF increased by $7.0 \pm 2.5 \%(\mathrm{p}<0,05)$, beat index also increased after the treatment to $36.1 \pm 3.5 \mathrm{ml} / \mathrm{m} 2$ from $28.99 \pm 2.2$ $\mathrm{ml} / \mathrm{m} 2$.

Therefore, while characterizing the efficiency of the prescribed medical preparation complexes in patients with liver cirrhosis the upmost manifested positive influence on the endothelial dysfunction indexes is shown by the treatment scheme of patients from group 3 (simultaneous usage of probiotics, Larginine medical preparations in combination with angiotensin II receptor blockers - valsartan). Under the influence of the treatment of patients from group 3 the EDVD and EIVD indexes increased by 2.3 to 1.6 times compared with the corresponding indexes before the treatment. In patients from group 1 and 2 an increase of EDVD and EIVD by merely 1.6-1.2 times and correspondingly 1.5-1.1 times was observed.

While assessing the efficiency of the proposed schemes of treatment on laboratory indexes of dysfunction of endothelium in patients with liver cirrhosis, it was determined that angiotensin-converting enzyme inhibitors and nonselective $\beta$-adreno-blocking agents manifest almost the same influence on the level of endothelin-1, von Willenbard factor, antithrombin III and D-dimer, but a less significant one, than the treatment with the use of angiotensin II receptor blockers. While identifying prostaglandin indexes in patients with liver cirrhosis, the same tendency was realised in their dynamics as in the above mentioned laboratory markers of the dysfunction of endothelium, namely, supremely manifested positive changes were observed in the indexes of patients from group 3. In line with this, the usage of valsartan leads to minimal frequencies of the system vessel pressure, and, also positively influences cardio hemodynamic indexes in patients with liver cirrhosis.

Considering the results of our studies the following conclusion was made: a complex pathogenically based treatment in patients with liver cirrhosis has to include the prescription of prebiotics and L-arginine medical preparations in combination with probiotics. L-arginine is a relatively indispensable amino acid, it is a broad cell regulator of many vital functions of the organism, it performs a hepatoprotector effect with the help of anti-oxidant, anti-hypoxic and membrane stabilizing activity, plus positively effects the processes of energy supply in hepatic cells. Arginine is also a substrate for NO-synthase, an enzyme that catalyzes the NO synthesis in endothelial cells, which determines its key role in regulating vessel tonus in patients with diseases that circuits with the damage of vessel walls [1,3]. At the same time, the usage of probiotics in order to decrease the manifestation of intestinal microbiocinosis helps normalize the amino acid reserves of blood serum, which increases positive influences on indexes of dysfunction of endothelium. Therefore, it is considered potential to use L- 
arginine medical preparations, probiotics in complex treatment and preventive treatment of the development of portal hypertension in patients with liver cirrhosis.

Also, in order to normalize the pressure in the portal system of patients with liver cirrhosis angiotensin II receptor blockers can be used there, where the usage of $\beta$-adreno-blocking agents is restricted. As the $\beta$-adreno-blocking agents, valsartan leads to minimal decrease in the system arterial pressure indexes, this is very important in the treatment of patients with liver cirrhosis. At the same time, angiotensin II receptor blockers manifest the most positive effect on the laboratory and instrumental indexes of dysfunction of endothelium in combination with L-arginine medical preparations and probiotics, thus it is necessary to include during the complex treatment of these patients.

In patients from group 3, a stable positive effect on indexes of dysfunction of endothelium was gained throughout the treatment course. A similar, but less significant tendency of endothelial dysfunction indexes correction was registered in the treatment using $\beta$-blockers, with an improvement of life quality; inhalation correction, decrease in ascite, adema.

System endothelial dysfunction in patients with liver cirrhosis is manifested in a rapid progression of laboratory and instrumental indexes of the dysfunction of endothelium that is especially manifested in patients of class $\mathrm{C}$ of Child-Pugh. The results confirm the data, which is available in literature, about rapid progression of laboratory markers of the dysfunction of endothelium in system circulation in decompressed forms of liver cirrhosis. Up to this moment the problem of endothelial dysfunction and its correction during diffusive liver diseases has been hardly studied. Our studies allow us to view endothelial dysfunction and the change of its laboratory indexes (endothelin-1, von Willenbard factor, and prostaglandins in plasma), as one of the important links in pathogenesis of portal hypertension and the development of a hyperhdynamic blood circulation type.

During the progression of the pathogenic process a damage to endothelium liver sinusoid cells occurs with a further activation of liver mononuclear cells, that leads to an increase in cytokine production, free radicals and collagen, as a result of this a change of sinusoid fenestration, collagenization of Disse space and an increase of the inner liver vessel resistance. This leads to nascence of preliver blood deployment through natural portoctaval anastomoses which, along with inner-liver and portocaval shunts, leads to a rapid decrease of the volume of liver blood supply [6]. This leads to ischemia, necrosis of the liver tissue with further fibrosis and defection of the liver architectonics.

Portal hypertension, which leads to varicose hemorrhage and ascites, is a severe complication of liver cirrhosis associated with high death rate. Improvement of the treatment methods of liver diseases is associated with 
problems of early manifestation of central and porto-liver hemodynamics defection and their prompt correction, namely through restoring endothelium structure and functions system and liver blood capillary. Systemic endothelial dysfunction with defection of laboratory markers of the dysfunction of endothelium concentration in liver cirrhosis with portal hypertension carries a universal character. A treatment with angiotensin II receptor blockers and betablockers is pathogenically optimal in formation of portal hypertension in patients with liver cirrhosis on the background of basic treatment in combination with prebiotics, probiotics and L-arginine medical preparations. Endothelial dysfunction and intracardic hemodynamics indexes normalization, which occurs on the background of complex treatment, points out the improvement of the elastic abilities of vessel walls and displays the positive influence of this treatment scheme on the process of vessel remodeling.

\section{Conclusions}

1. Complex treatment in patients with liver cirrhosis with the usage of valsartan in combination with prebiotics, probiotics and L-arginine medical preparations is well tolerated by the patients and does not significantly influence the indexes of system arterial pressure.

2. Complex treatment with the usage of prebiotics, probiotics, L-arginine medical preparations and angiotensin II receptor blockers in patients with liver cirrhosis and portal hypertension is an effective pathogenically proven method for the dysfunction of endothelium indexes and central hemodynamics correction.

3. Medical preparations, valsartan, are an alternative in complex treatment of patients with liver cirrhosis for normalizing the endothelial dysfunction in combination with prebiotics, probiotics and L-arginine medical preparations for the preventive treatment of hemorrhages of varicose veins of esophagus and stomach. 


\section{References:}

1. Bai, V., Sun, L., Vang, S. et al. (2009): Increase in fastingvascular endothelial function after short-term oral L-arginine iseffective when baseline flow-mediated dilation is low: a meta-analysis of randomized controlled trials. Am. J. Clin. Nutr. 89 (1): 77 - 84.

2. Bosch, J., Berzigotti, A., Garcia-Pagan, J.C. et al. (2008): The management of portal hypertension: rational basis, available treatment and future options. J. Hepatol. 48: 68-93.

3. Chatterjee, A., Catayas, J. D. (2008): Endothelial nitric oxide (NO) and its pathophysiologic regulation. Vascul. Pharmacol. 49 (4 - 6): $134-140.1$

4. Fierbinteanu-Braticevici, C., Dragomir, P., Tribus, L., et al. (2006): The role of Valsartan, an Angiotensin II receptor antagonist, on portal and systemic hemodynamics and on renal function in liver cirrhosis. J. Gastrointest. Liver Dis. 15 (4): 337 - 342.

5. Hennenberg, M., Trebicka, J., Kohistani, A. Z. et al. (2009): Vascular hyporesponsiveness to angiotensin II in rats with $\mathrm{CCl}$ (4)-induced liver cirrhosis. Eur. J. Clin. Invest. 39 (10): 906 - 913.

6. Lugo-Baruqui, A., Munoz-Valle, J.F., Arevalo-Gallegos, S. et al. (2010): Role of angiotensin II in liver fibrosisinduced portal hypertension and therapeutic implications. Hepatol. Res. 40 (1): 95 - 104.

7. Mejias, M., Garcia-Pras, E., Tiani, C. et al. (2008): The somatostatin analogue ocreotide inhibits angiogenesis in the earliest, but not in advanced, stages of portal hypertension in rats. J. Cell Mol. Med. 12: 1690 $-1699$.

8. Бабушкина, А. В. (2009): L-аргинин с точки зрения доказательной медицины / А.В. Бабушкина. Український медичний часопис 6 (74): $43-48$.

9. Грюнграйфф, К., Ламберт-Бауманни (2008): Эффективность гранул Lорнитин-L-аспартата при лечении хронических заболеваний печени. Сучасна гастроентерологія 2: 26 - 33.

10. Ермолова, Т. В., Шабров, А. В., Ермолов, С. Ю., Олейник, В. В. (2009): Изучение эффективности L-орнитина-L-аспартата (Гепа-мерц) в профилактике послеоперационных осложнений у больных хроническими заболеваниями печени. Острые и неотложные состояния в практике врача 5: $26-28$.

11. Русин, В. І., Сірчак, С. С., Петричко, О. І., Івачевський, М.М. (2011): Корекція ендотеліальної дисфункції у хворих на цироз печінки. Український журнал хірургії 2 (11): 9 - 13. 
12. Скрипник, I. М., Гапко, О. Ф. (2010): Кровотечі з варикозно розширених вен стравоходу: діагностика, лікування та профілактика. Здоров'я України 4: $44-45$.

13. Степанов, Ю. М., Кононов, И. Н. (2007): Основные причины кровотечений при заболеваниях печени. Здоров'я України 7 (1): 33 35.

14. Чекман, I. С., Харченко, Н. В., Анохіна, Г. А. (2010): Клінікофармакологічні властивості та особливості застосування комбінованого гепатопротекторного препарату «Гепадиф®» як середника терапії супроводу при прийомі статинів. Сучасна гастроентерологія 4 (54): 88 - 93.

Rusin V.I., Sirchak E.S., Ivachevskij M.M., Petrichko O.I.

Uzhhorod National University, Medical Department (Ukraine, Uzhhorod) 